\title{
Örgütsel Vatandaşlık Davranış1 İle Demografik Özellikler Arasındaki İlişkinin CHAID Analizi İle İncelenmesi: Bankacılık Sektöründe Bir Araştırma ${ }^{1}$
}

\section{Özgül CAMGÖZ² ve Zübeyir BAĞCI ${ }^{3}$}

\section{$\ddot{O} z$}

$\mathrm{Bu}$ çalıșmanın amacı çalıșanların ortaya koydukları öroütsel vatandașlık davranıșı ile onların çeșitli demografik özellikleri arasındaki ilişkiyi incelemektir. Bu amaçla özel bir bankanın 172 çalışanı üzerinde bir araştırma gerçekleştirilmiştir. Gerekli olan veriler anket tekniği ile toplanmıştır. Verilerin analizinde CHAID analizinden yararlanılmıştır. $\mathrm{Bu}$ analizin tercih edilmesinin nedeni regresyon analizi için gerekli olan varsayımlara (normallik, doğrusallık, homojenlik gibi) ihtiyaç duymamasıdır. Analiz sonucunda çalışanların örgütsel vatandaşlık davranışlarının çalışma süresi, eğitim, cinsiyet, medeni durum ve yaş gibi demografik özellikler ile ilişkili olduğu belirlenmiştir.

Anahtar Kelimeler: Örgütsel Vatandaşlık Davranışı, Demografik Özellikler, CHAID Analizi

The Investigation of the Relationship between Organizational Citizenship Behavior and Some Demographic Properties by CHAID Analysis: A Research in the Banking Sector

\section{Abstract}

The aim of this study is to investigate the relationship between the organizational citizenship behavior and the various demographic characteristics of the employees. For this purpose, a survey was carried out on 172 employees of a private bank. The required data were collected by survey technique. CHAID analysis was used to analyze the data. The reason why this analysis is preferred is that it does not need the assumptions (such as normality, linearity, homogeneity) required for regression analysis. As a result of the analysis, it was determined that the organizational citizenship behaviors of the employees are related to the demographic characteristics such as seniority, education, gender, marital status and age.

Key Words: Organizational Citizenship Behavior, Demographic Characteristics, CHAID Analysis

\section{Atıf İçin / Please Cite As:}

Camgöz, Ö. ve Bağcı, Z. (2020). Örgütsel vatandaşlık davranışı ile demografik özellikler arasındaki ilişskinin CHAID analizi ile incelenmesi: Bankacılık sektöründe bir araştırma. Manas Sosyal Araştırmalar Dergisi, 9(2), 958-972.

Geliş Tarihi / Received Date: 05.02.2019

Kabul Tarihi / Accepted Date: 13.11.2019

\footnotetext{
${ }^{1} \mathrm{Bu}$ makale Özgül Camgöz’ün "Personeli Güçlendirmenin Örgütsel Vatandaşlık Davranışı Üzerindeki Etkisi ve Bir Araştırma” Başılıkı Yüksek Lisans Tezinden Üretilmiştir.

2 Doktora Öğrencisi - Katip Çelebi Üniversitesi SBE, ozgul_2006@hotmail.com - ORCID: 0000-0002-3074-9122

${ }^{3}$ Doç. Dr. - Pamukkale Üniversitesi İ̈BF, zbagci@pau.edu.tr - ORCID: 0000-0001-7902-1485
} 


\section{Giriş}

Günümüz iş dünyasında örgütlerin başarısının ve verimliliğinin ana unsuru insan faktörüdür. Çalışanlara verilen önem arttıkça, çalışanların duygularının, tutumlarının, beklentilerinin ve davranışlarının sebepleri anlaşıldıkça örgütsel başarı da beraberinde gelmektedir.

Rekabetin yoğun bir biçimde etkisini gösterdiği günümüz iş yaşamında çalışanların yalnızca sözleşmelerinde bulunan ve yapmakla yükümlü oldukları görevleri yerine getirmesi yeterli olmamaktadır. Örgütler görev tanımlarının dışına çıkabilen çalışanlara ihtiyaç duymaktadır. Herhangi bir denetim mekanizması olmadığı durumlarda bile görevlerini tam manasıyla yerine getiren, örgüt içinde fazladan görev alan, örgüt içi yardımlaşmayı sağlayan, örgütsel gizliliğge önem veren çalışanlar günümüz örgütlerinin başarısında kilit rol oynamaktadır. Örgütsel vatandaşlık davranışı olarak ifade edilen söz konusu bu davranış biçimleri birçok araştırmacının dikkatini çekmiş ve çok sayıda araştırmaya konu olmuştur. Örgütsel vatandaşılı davranışı ile ilgili yapılan tanımların ortak noktası çalışanların kendi isteklerine bağı olarak gönüllülük esası ile kendilerinden beklenenin ötesinde bir davranışta bulunmalarıdır. Nitelikli iş gücü değişen iş yaşamında başarılı olmak isteyen örgütlerin temel aktörüdür. Bu nedenle nitelikli iş gücünü örgüt bünyesinde barındırmak oldukça önemli bir durum haline gelmiştir.

Ülkemizde bankalar, sigorta şirketleri, yatırım fonları, yatırım ortaklıkları, yatırım danışmanlığı şirketleri, portföy yönetim şirketleri, leasing ve faktoring kuruluşlarılyla birlikte finansal alanda faaliyet gösteren aktörlerden biridir (Ünal, 2014, s. 8). Finansal sistem içerisinde en önemli pay bankalara aittir. Bankacıllk faaliyetlerinin aktif ve istikrarlı bir biçimde yürütülmesi ekonomiyi olumlu yönde etkilemektedir. Bankaların tarafindan yürütülen finansal faaliyetler ekonominin gelişmesine, verimliliğin ve toplumsal refah düzeyinin artmasına katkıda bulunur. Genel anlamda bankalar gerçek ve tüzel mevduat sahiplerinden kaynakları toplayan, kaynakları ödünç alan ve ödünç veren, ekonomide kaydi paranın oluşturulmasını sağlayan, devamlı olarak ekonomik faaliyetleri gerçekleştiren kuruluşlardır. Bankalar kar elde etmek amacıyla kurulan işletmelerdir. Bankalar finansal aracilık yapmak, likidite oluşturmak, kredi talebinde bulunanları değerlendirmek, para politikaların etkin bir biçimde yürütülmesini sağlamak, ekonomide büyüme ve istikrar sağlamak, ölçek ve kapsam ekonomilerinden yararlanmak, ödeme sistemlerinin etkin bir biçimde işlemesini sağlamak, ihracatın artmasını sağlamak gibi ülkelerin finansal sistemleri için oldukça önemli işlevlere sahiptir (Sı̆̆maz, 2017, s. 40). Bankalar, temel işlevleri olan mali aracıllk ile fon arzı ve talebi oluştururlar. Bu sayede bir yandan mali piyasalarda büyüme gerçekleşirken bir yandan da milli gelir ve istihdamda artış sağlanmış olur (Savram ve Karakoç, 2012, s. 318).

Tüm örgütler gibi bankalar da, bağlllık duygusu gelişmiş, sorumluluklarının ötesinde gönüllü bir çaba gösteren iş gücüne sahip olmayı talep etmektedirler. Bu bağlamda çalışanlardan beklenen davranışlar örgütsel vatandaşlık davranışı olarak nitelendirilebilir. Örgütsel vatandaşlık davranışı çalışanların performansına yansımakta ve onları olumlu veya olumsuz etkilemektedir. Örgütsel yaşamda ortaya çıan değişimlere kolayca adapte olma gerekliliğinden dolayı örgütlerin çalışanlardan bekledikleri bir davranış biçimi haline gelmiştir. Bu çalışmanın amacı hem örgüte hem çalışana olumlu etkileri olan örgütsel vatandaşlık davranışının çeşitli demografik özellikler ile olan ilişkisini ortaya koymaktır.

Örgüt, bireylerin bir araya gelmesi, aralarında iş bölümü yapması, ortak bir amacı benimsemesi ve sorumluluk alması ile oluşan bir yapılanmadır. Vatandaşlık ise, bireyler ve devlet arasında anayasada tanımlanmış, bireyin ve devletin karşılıklı hak ve ödevleridir. Örgütsel vatandaşlık ise, bireyin örgüte olan sorumluluklarını ifade eder. Örgütsel vatandaşlıkta vatandasslık tanımında bulunan devletin yerini örgüt almaktadır. Ayrıca; örgütsel vatandaşlıkta belirli bir zorunluluğa veya kurallara bağlı kalmaksızın fazladan bir çaba söz konusudur (Yücel ve Kaynak, 2008, s. 685).

Bir ülkede vatandaşlar ülke yönetimi tarafindan belirlenen kurallara uymak dışında ülkesi için ekstra olumlu davranışlarda da bulunurlar. Bu davranışlar "herkesin kapisının önünü temizlemesi durumunda sokakların pırıl pırıl olacă̆ı" düşüncesinden kaynaklanmaktadır. Aynı inanç örgütlerde de geçerlidir. Bireyler ne kadar sorumlulukları dışına çıkar ve örgütsel hedefler doğrultusunda fazladan rol davranışında bulunurlarsa örgütsel hedeflere ulaşmak o derece kolaylaşır (Ala, 2010, s. 4). Örgütsel vatandaşlık davranışı isteğe bağlı ortaya çıkan davranışlardır. Çalışanların resmi rollerinin ötesinde, örgütlerin performansında da önemli rol oynarlar (Yoon, 2009, s. 421). Örgütsel vatandaşlık davranışı çalışanlara ve örgüte yardımc1 olmayı amaçlayan, psikolojik sözleşmenin ötesine geçen gönüllü katkılardır (Spektor ve Fox, 2002, s. 2). Çalışanların örgütte biçimsel yolla belirlenen, yapılması zorunlu olanların ötesine geçmesi ve beklenenden fazlasını yapmalanıdır (Çetinkaya ve Çimenci, 2014, s. 244). Örgütsel vatandaşlık davranışı, çalışanların iş 
tanımında bulunmayan, herhangi bir eğitim faaliyetine bağlı olmayarak meydana gelen, ödüllendirme veya cezalandırma sistemine tabii tutulmayan davranışlardır (Bolino, 1999, s. 83).

Örgütsel vatandaşlık davranışı ikiye ayrılmaktadır. Birinci tür örgütsel vatandaşlık davranışı; örgütsel faaliyetler içerisinde aktif bir biçimde bulunan davranışlardır. İkinci tür örgütsel vatandaşlık davranışı ise örgütsel yapıya zarar verecek olan davranışlardan kaçınma olarak ifade edilebilir. Söz konusu bu iki tür arasında ciddi farklılıklar mevcuttur. Örgüte katk1 sağlamayı amaçlayan birinci tür örgütsel vatandaşlık davranışı biçiminde çalşsanlar örgüt içinde aktif biçimde rol alırlar. Kendi çabaları sayesinde üretim yaparlar. İkinci tür örgütsel vatandaşlık davranışında ise çalışanlar yalnızca örgüte zarar vermeme düşüncesiyle hareket ederler. Temel amaç örgütün zararına olacak faaliyetlerde bulunmamaktır. $\mathrm{Bu}$ bağlamda söz konusu farklılık bir futbol maçına benzetilebilir. Bir futbol maçını kazanmak için oynamak ile kaybetmemek için oynamak aynı şey değildir (Karaman ve Aylan, 2012, s. 38; Avc1, 2015, s. 193). Temelde örgütsel vatandaşlık davranışı iki türlü olsa da uygulamada her ikisi de talep edilmekte ve örgütler tarafindan çalışanlarından beklenen davranış biçimleri arasında yer almaktadır.

İlgili literatür incelendiğinde örgütsel vatandaşlık davranışını oluşturan boyutlar konusunda bir fikir birliğine varılamadığı görülmektedir. Ancak konuyla ilgili yapılan çeşitli çalışmalarda (Aydoğan ve Dinçer, 2017; Khan vd., 2017; Alkahtani, 2015; Kittilertpaisan vd., 2014; Tambe ve Shanker, 2014; Moorman, 1991) genellikle Organ (1988) tarafindan ortaya konulan ve özgecilik (altruism), vicdanlillk (conscientiousness), nezaket (courtesy), centilmenlik (sportmenship) ve sivil erdem (civil virtue) olmak üzere beș alt boyuta sahip olan modelin kullanıldığı söylenebilir. Bu alt boyutlar içerisinden özgecilik ve nezaket alt boyutları bireye yönelik iken; vicdanlllık, sivil erdem ve centilmenlik alt boyutları örgüte yöneliktir (Şahin ve Açar, 2017, s. 1096).

Ö̊gecilik: Özgecilik boyutu, örgüt içinde bireylerin karşlık beklemeden birbirine yardımcı olmaları, sorunların çıkmasını engellemek amacıyla gönüllü çaba göstermeleridir (Podsakoff vd., 2000, s. 518). Özgecilik, örgüt içinde bireylere yardım etmeyi amaçlayan davranışların tamamıdır. Özgecilik davranışı ile bireyler arasındaki iş birliği artmaktadır. Bireyler arasında artan iş birliği sayesinde örgüt içerisinde meydana gelebilecek olan gerginlikler ve çatışmalar önlenebilmektedir. Örgüt içerisindeki ilişkiler olumlu etkilenmektedir (Budak, 2015, s. 13). Yardıma ihtiyacı olan veya işe yeni başlayan arkadaşlarına yardım talebi bulunmadan, kendi isteği ile yapılan yardımdır. Kıdemli veya uzman çalışanların işe yeni başlayanlara bilgi ve deneyimlerini aktarması olarak ifade edilebilir. Yardımlaşmanın ön plana çıktığı özgecilik davranışı örgütsel etkinliğin ve verimliliğin artmasına katkıda bulunur. Örgüt içinde bulunan araç ve gereçlerin kullanımı, herhangi bir proje veya sunum hazırlı̆̆ında bilgi alşsverişi yolu ile çalışmaların birbirini tamamlamaları özgecilik için verilebilecek güzel bir örnektir (Allison vd., 2001, s. 283). Yardımlaşma eyleminin doğası düşünüldügünde çalışanlar arasında pozitif yönlü bir ilişki gelişmektedir. Örgüt içerisinde herhangi bir işi birlikte yapmaları aralarında iş birliğini arttırarak birlik ve beraberlik duygusu içerisinde güvenle çalışmalarını sağlamaktadır.

Nez̧aket: Çalışanların örgüt içerisinde meydana gelebilecek herhangi bir problemi önleme veya ortaya çıkması muhtemel herhangi bir problemin engellenmesi için diğer çalışanlara yardımcı olmayı ifade eder. Kısaca; herhangi bir problemin meydana gelmesini beklemeden problem oluşturabilecek durumları gönüllü biçimde önlemektir. Nezaket davranışına örnek olarak çalışanlara önceden bilgi verme, danışmanlık yapma, hatırlatma gibi davranışlar verilebilir. Nezaket ve özgecilik kavramları birbirine çok benzer kavramlar olarak görülse de aralarında farklılıklar mevcuttur. Özgecilik boyutu problem ortaya çıktıktan sonra görülen davranışları ifade ederken nezaket boyutu herhangi bir problemin ortaya çıkmasını engellemeye yönelik davranışları ifade eder (Budak, 2015, s. 13).

Vicdanlllk: Vicdanllık örgütsel düzeni sağlayan kurallara uyma davranışıdır. Çalışanların kurallara uyma konusunda gayretli ve istekli olmasıdır. Vicdanlılık boyutu "kişisel gayret", "ileri görev bilinci" ya da "genel uyum" olarak da ifade edilmektedir (Mahmutoğlu, 2017, s. 51). Vicdanlllik boyutunun temelinde fazladan rol davranışı bulunmaktadır. Çalışanların örgüt beklentisi olan asgari rol davranışının ötesinde rol davranışında bulunmasıdır. Söz konusu fazladan rol davranışı gönüllülük esasına dayanmaktadır (Karaman ve Aylan, 2012, s. 39). Örgütsel düzeni sağlayan kurallara bağlı kalarak görevini yerine getirmesi vicdanlllkk boyutuna örnektir. Çalışanların örgütün başarısını ve performansını arttırmak amacıyla gönüllü olarak fazladan sorumluluk üstlenmeleri, yaratıcı davranmaları, yenilikçi olmaları aynı zamanda diğer çalışma arkadaşlarını da bu şekilde davranmaları için teşvik etmeleri, onları cesaretlendirmeleri vicdanllık boyutuna örnek davranış biçimleridir (Podsakoff vd., 2000, s. 524). Vicdanlllık boyutunda çalışanlar üstün görev bilincine sahiptir. Çalsşanlar örgütün kurallarına gönüllü olarak uymaktadır. Herhangi bir denetim 
mekanizması yokken bile kurallar doğrultusunda hareket ederek örgütsel amaçları gerçekleştirmeye çalışırlar.

Sivil Erdem: Sivil erdem boyutu çalışanların örgüte bağlllıkları ve sorumluluk duyguları ile ilgilidir. Örgüt içinde düzenlenen toplantıların hepsinde eksiksiz bulunma, toplantılarda meydana gelecek tartışmalarda fikirlerini özgürce beyan etme, örgütsel kararlara katılma, kendilerini geliştirmek amacıyla eğitim faaliyetlerinde bulunma, örgüt için fırsat veya tehdit olarak algılanabilecek durum ve koşulları gözlemleme, örgüt ile ilgili konularda bilgi sahibi olma sivil erdem boyutunda meydana gelebilecek davranış biçimleridir (Ulusoy ve Sarıçoban, 2017, s. 660). Yetki ve sorumluluğun üst kademe yöneticilerde toplandığı, hiyerarşik bir düzenin olduğu, kararların yalnızca üst kademe yöneticiler tarafından alındığı ve otoriter bir yönetim sistemi belirleyen örgütlerde sivil erdem davranış1 uygulamaya dâhil edilememektedir. Otoriter bir yönetim sistemini benimseyen söz konusu örgüt yöneticileri çalışanların fikir beyanlarını kabul etmezler. Çalışanların fikirlerini ortaya koymaları yöneticilerin işlerine karışmaları olarak düşünülür. Sivil erdem davranışı çalışanlara inisiyatif tanınan, yetki devrinin yapıldığ1 örgüt yapılarında görülebilecek bir davranış biçimidir (Çelik, 2007, s. 135).

Centilmenlik/Sportmenlik: Centilmenlik davranışı sakınma davranışı olarak görülmektedir. Çalışanların problem yaratacağını düşündüğü davranışlardan uzak durmasıdır (Podsakoff ve MacKenzie, 1997, s. 142). Söz konusu bu özellikleri itibariyle örgütsel vatandaşlık davranışının centilmenlik boyutu, çalışanların bardağın dolu tarafına bakması halidir. Çalışanların örgütlerde meydana gelmesi doğal olan olumlu veya olumsuz durumlarda olumluyu görebilme becerisine sahip olmalarıdır. Centilmenlik boyutu ile çalışanların motivasyonu artmakta ve bu bağlamda örgütsel başarı sağlanmaktadır. Centilmenlik, örgüt içinde huzuru ve barışı sağlar. Huzurlu bir çalışma ortamını gaye edinen ve bu ortamı gerçekleştiren çalışanlar genellikle centilmen olarak anılmaktadır. Hoşgörülü ve katlanma düzeyi yüksek çalışanlar örgütsel performansın artmasında etkilidir. Centilmenlik yalnızca şikâyet etmeme davranışı değildir. Centilmenlik aynı zamanda fedakârlık etme, olumlu tutumu devamlı olarak sürdürme davranışıdır. Çalışanın örgütte meydana gelebilecek sorunlar karşısında olumlu bir tutum sergileyerek soruna yaklaşması, çalışanlar arasında fikir birliği olmadığı durumlar da bile kendisinden fedakârlık yapması, başkalarının duygu ve düşüncelerine sayg1 duyması olarak da nitelendirilebilir (Çelik, 2010, s. 45).

Örgütsel vatandaşlık davranışının örgüt ve çalışanlar açısından olumlu sonuçları vardır. Örgütsel vatandaşlık davranışı sergileyen çalışanlara sahip örgütlerde çatışmalar azalmakta, örgütün performansı artmakta örgütsel faaliyetlerin uygulanması kolaylaşmaktadır (Gürbüz, 2006, s. 57). Örgütsel vatandaşlık davranışı iş yaşamını üç temel noktada fazlasıyla etkilemektedir. Bunlardan ilki yardımlaşmadır. Yardımlaşma eylemini amaç edinen bireyler iyi vatandaş olarak nitelendirilebilirler. Yardımlaşma sayesinde örgüt içinde iletişim güçlenecek, çalışanların arasında bilgi paylaşımı artacaktır. Yardımlaşma eylemi örgüte yeni katılan çalışanlar ve eski çalışanlar arasında uyumu kolaylaştıracak, örgütsel hedeflere iş birliği içinde kolayca ulaşacaklardır. Örgütsel vatandaşlık davranışının ikinci etkisi, çalışanların güçlü sorumluluk duygusuna sahip olmasını sağlamasıdır. Örgütsel başarının başında çalışanların fedakârlıkta bulunmaları gerekmektedir. Örgütlerine karşı sorumluluk duygusu gelişen bireylerin örgütsel amaçlara ulaşması kolaylaşmaktadır. Son etki ise çalışanların olumlu tutuma sahip olmaları ile ilgilidir. Örgütlerine karşı olumlu tutuma sahip olan bireylerin örgütsel başarısı yüksektir.

\section{Yöntem}

İlişkisel tarama modelinde tasarlanan bu araştırmanın amacı banka çalışanlarının ortaya koydukları örgütsel vatandaşlık davranışlarının çeşitli demografik özellikleriyle olan ilişkisini belirlemektir.

İlgili literatürde konuyla ilgili çalışmalar incelendiğinde örgütsel vatandaşlık davranışının cinsiyet, yaş ve çalışma süresi gibi demografik özelliklere bağlı olarak anlamlı farklılıklar göstermediği (Bakan vd., 2017; Berbaoui, 2015; Uzonwanne, 2014; Yeşiltaş ve Keleş, 2010) yönünde araştırma bulgularına rastlanılabildiği gibi demografik değişkenlerin örgütsel vatandaşlık davranışında belirleyici bir etkiye sahip olduğu (Tokgöz ve Seymen, 2013; Mahnaz, vd., 2013; Özyer vd., 2012) yönündeki araştırma bulgularına da rastlanılabilmektedir. Bu nedenle araştırma kapsamında şu sorulara cevap aranmıştır:

- Çalışanların örgütsel vatandaşlık davranışlarında cinsiyete atfedilebilecek istatistiksel olarak anlamlı bir farklilik var midir?

- Çalışanların örgütsel vatandaşlık davranışlarında yaşa atfedilebilecek istatistiksel olarak anlamlı bir farklilik var midir? 
- Çalışanların örgütsel vatandaşlık davranışlarında medeni duruma atfedilebilecek istatistiksel olarak anlamlı bir farklilık var midir?

- Çalışanların örgütsel vatandaşlık davranışlarında eğitime atfedilebilecek istatistiksel olarak anlamlı bir farklilik var midir?

- Çalışanların örgütsel vatandaşlık davranışlarında çalışma süresine atfedilebilecek istatistiksel olarak anlamlı bir farklilık var midır?

\section{Evren - Örneklem}

Araştırmanın evrenini özel bir bankanın Denizli ili ve ilçelerinde bulunan şubelerinde görev yapan toplam 200 banka çalışanı oluşturmaktadır. Örneklem seçilmeksizin tüm evrene dağıtılan anketlerden 176 tane geri dönüş sağlanmışır. Hatalı ve eksik doldurma sonucu 4 adet anket geçersiz sayılmıştır. Anketlerin geri dönüş oran1 $\% 86$ 'dır.

\section{Veri Toplama Araçları}

Örgütsel Vatandaşlık Davranısı Ölçeği. Orijinali Vey ve Campbell (2004) ile Williams ve Shiaw (1999) tarafindan geliştirilen ve Basım ve Şeşen tarafindan (2006) geçerliliği ve güvenilirliği test edilmiş olan bir ölçektir. Beş alt boyuta sahip olan bu ölçekte özgecilik alt boyutunda 5 madde, vicdanlıllk alt boyutunda 3 madde, nezaket alt boyutunda 3 madde, centilmenlik alt boyutunda 4 madde ve sivil erdem alt boyutunda 4 madde olmak üzere toplamda 19 madde bulunmaktadır. Katılımcıların ölçeklere verecekleri cevapları ise 1: Kesinlikle katılmiyorum, 2: Katılmıyorum, 3: Kararsızım, 4: Katıliyorum, 5: Kesinlikle katıliyorum şeklinde beşli Likert ölçeğine göre düzenlenmiştir. Bu çalışmada ölçeğin hesaplanan Cronbach's alpha iç tutarl111k katsayis1 0,925’tir.

\section{Verilerin Analizi}

Demografik özellikler ile katılımcıların örgütsel vatandaşlık davranışı göstermeleri arasındaki ilişki CHAID analizi ile değerlendirilmiştir. CHAID analizi (Ki-kare Otomatik Etkileşim Tespiti) bir veri segmentindeki değişkenler arasındaki yapısal bağlantıları analiz etmek için kullanılan yöntemlerden biri olan bir tür AID (Otomatik Etkileşim Tespiti) yöntemidir (Atti ve Dodo, 2018, s. 185). CHAID analizi ile kategorik değişkenlerden oluşan veri seti ve bağımlı değişken kendilerini en iyi şekilde açıklayabilecek tarzda ayrıntılı homojen alt kümelere bölünür. Bu sayede dağlımın normalliği ve homojenliği sağlanmıss olur. Ortaya çıkan bu alt kümeler küçük tahmin edici gruplardan meydana gelmektedir. En iyi tahmini ortaya koyabilmek için başlangıç değiş̧kenleri sürekli olarak bağımsız bir şekilde yeniden kategorileştirilerek analiz sürdürülür (Doğan, 2003, s. 66). CHAID analizi sayesinde sadece bağımlı değişken ile bağımsız değişkenler arasındaki ilişki belirlenmekle kalmamakta aynı zamanda bağımsız değişkenlerin kendi aralarındaki etkileşimleri de ortaya konulmuş olmaktadır (Şahin ve Avcıkurt, 2013, s. 318).

\section{Bulgular}

Katılımcıların demografik özelliklerine ilişkin dağılımları Tablo 1'de sunulmuştur.

Tablo 1. Katıllmoılarn Demografik Özellikelerine Göre Dağgllmlar

\begin{tabular}{|c|c|c|c|c|}
\hline & & Frekans & Yüzde & Kümülatif \\
\hline \multirow{2}{*}{ Cinsiyet } & Kadin & 71 & 41,3 & 41,3 \\
\hline & Erkek & 101 & 58,7 & 100,0 \\
\hline \multirow{3}{*}{ Yaş } & 19-25 Yaş & 13 & 7,6 & 7,6 \\
\hline & 26-44 Yaş & 130 & 75,6 & 83,1 \\
\hline & 45-59 Yaş & 29 & 16,9 & 100,0 \\
\hline \multirow{2}{*}{ Medeni Durum } & Evli & 109 & 63,4 & 63,4 \\
\hline & Bekâr & 63 & 36,6 & 100,0 \\
\hline \multirow{3}{*}{ Eğitim Durumu } & Ön lisans & 41 & 23,8 & 23,8 \\
\hline & Lisans & 119 & 69,2 & 93,0 \\
\hline & Yüksek Lisans & 12 & 7,0 & 100,0 \\
\hline \multirow{6}{*}{ Çalışma Süresi } & 1 yildan az & 13 & 7,6 & 7,6 \\
\hline & $1-5$ y1l & 29 & 16,9 & 24,4 \\
\hline & $6-10 \mathrm{y} 1 \mathrm{l}$ & 56 & 32,6 & 57,0 \\
\hline & $11-15 \mathrm{yll}$ & 51 & 29,7 & 86,6 \\
\hline & $16-20 \mathrm{y} 1 \mathrm{l}$ & 22 & 12,8 & 99,4 \\
\hline & 21 yll ve üzeri & 1 & 0,6 & 100,0 \\
\hline
\end{tabular}


Tablo 1 incelendiğinde 172 kişilik katıllımcı grubunun \% 41,3'ünün (71 kişi) kadınlardan oluştuğu görülmektedir. Katılımcıların çoğunluğunun \%75,6 ile (130 kişi) 26-44 yaş aralığındaki katılımcılar oluştuğu ve bunları sırasıyla $\% 16,9$ oranı ile (29 kişi) 45-59 yaş aralığındaki katılımcıların ve \%7,6 oranı ile (13 kişi) 19-25 yaș aralı̆̆ındaki katılımcıların izlediği söylenebilir. Katılımcıların \%63,4'ü (109 kişi) evlidir. Eğitim durumlarına göre dağılımlarına bakıldığında katılımcıların \%69,2'sinin (119 kişi) lisans mezunu, \%23,8'inin (41 kişi) ön lisans mezunu, \%7'sinin (12 kişi) yüksek lisans mezunu olduğu görülmektedir. Bu oranlardan anlaşılacağ1 gibi katılımcıların çok büyük bir çoğunluğu lisans mezunudur. Katıllmcıların kurumda çalıştıkları süreye göre dağllımlarına bakılırsa; \%7,6's1 (13 kişi) 1 yıldan az, \%16,9’u (29 kişi) 1-5 yll arası, \%32,6's1 (56 kişi) 6-10 yll aras1, \%29,7'si (51 kişi) 11-15 yıl aras1, \%12,8’i (22 kişi) 16-20 y1l arası ve son olarak \%0,6's1 (1 kişi) 21 yll ve üzeri çalışma süresine sahiptir.

Örgütsel Vatandaşlık Davranışı ölçeğinin yapı geçerliliği için faktör analizinden ve güvenilirliği için de Cronbach's Alpha iç tutuarlılık katsayısından yararlanılmıştır.

Faktör analizi öncesinde eldeki veriler faktör analizi için uygunluk açısından incelenmiştir. Bunun için KMO değeri ile Barlett küresellik testi sonuçlarına bakılmıştır. Buna göre örgütsel vatandaşlık davranışı ölçeğinin KMO değerinin 0,913 ve Barlett testi sonucunun 1705,466 ( $p<0,000)$ olduğu görüldüğünden eldeki verilerin faktör analizi uygulamaya elverişli olduğuna karar verilmiştir. Özdeğeri 1'den büyük olan faktörler ölçeğe dâhil edilmiş olup faktör yük değerleri için 0,40 alt sınır olarak belirlenmiştir. Yapılan faktör analizi sonucunda elde edilen faktörlerin sahip oldukları yükler ise tablo 2'de yer almaktadır.

Tablo 2. Örgütsel Vatandaşlhk Davranışlar Ölçeğindeki Faktör Yükleri

\begin{tabular}{|c|c|c|c|c|c|}
\hline \multirow[b]{2}{*}{ MADDELER } & \multicolumn{5}{|c|}{ FAKTÖRLER } \\
\hline & Fak 1 & Fak 2 & Fak 3 & Fak 4 & Fak 5 \\
\hline Özgecilik 2 & 0,510 & & & & \\
\hline Özgecilik 3 & 0,800 & & & & \\
\hline Özgecilik 4 & 0,704 & & & & \\
\hline Özgecilik 5 & 0,671 & & & & \\
\hline Vicdanllilk 1 & & 0,817 & & & \\
\hline Vicdanll11k 2 & & 0,625 & & & \\
\hline Vicdanll1tk 3 & & 0,583 & & & \\
\hline Nezaket 1 & & & 0,601 & & \\
\hline Nezaket 3 & & & 0,985 & & \\
\hline Centilmenlik 1 & & & & 0,803 & \\
\hline Centilmenlik 2 & & & & 0,747 & \\
\hline Centilmenlik 3 & & & & 0,700 & \\
\hline Centilmenlik 4 & & & & 0,687 & \\
\hline Sivil Erdem 1 & & & & & 0,451 \\
\hline Sivil Erdem 2 & & & & & 0,646 \\
\hline Sivil Erdem 3 & & & & & 0,768 \\
\hline Sivil Erdem 4 & & & & & 0,767 \\
\hline \multirow[t]{2}{*}{ Açıklanan Varyans (\%) } & 20,875 & 16,352 & 15,894 & 8,887 & 6,487 \\
\hline & & & 68,495 & & \\
\hline \multirow[t]{2}{*}{ Cronbach's Alpha $(\alpha)$} & 0,733 & 0,706 & 0,600 & 0,810 & 0,741 \\
\hline & & & 0,925 & & \\
\hline
\end{tabular}

Tablo 2'de görüldüğü üzere özgecilik faktöründe yer alan maddelerden biri 0,40 değerinden daha düşük bir faktör yüküne sahip olduğu için ölçekten çıkarılmıştır. Geriye kalan maddelerin faktör yükleri 0,510 ile 0,800 arasında değişmektedir ve faktörün açıkladığı toplam varyans miktarı \%20,875'tir. Vicdanlılık faktörünün faktör yükleri 0,583 ile 0,817 arasında değişmektedir ve açıkladığ toplam varyans miktar1 \%16,352'dir. Nezaket faktöründe yer alan maddelerden biri faktör yükü alt sınırı olan 0,40 değerinden daha düşük bir değer aldığı için ölçekten çıkarılmıştır. Geriye kalan maddelerin faktör yükleri 0,601 ile 0,985'tir ve bu faktör toplam varyansın \%15,864'ünü açılamaktadır. Centilmenlik faktörünün faktör yükleri 0,687 ile 0,803 arasında değişmektedir ve açıkladığı toplam varyans miktarı \%8,887'dir. Sivil erdem faktörünün faktör yükleri ise 0,451 ile 0,768 arasında değişmekte olup açıkladığı toplam varyans miktarı da \%6,487'dir. Ölçeğin bütününe ilişkin Cronbach's Alpha değeri 0,925 olarak bulunmuştur. Alt boyutların Cronbach's Alpha değerleri ise özgecilik için 0,763, vicdanllık için 0,706, nezaket için 0,600, centilmenlik için 0,810 ve sivil erdem için 0,741 olarak hesaplanmıştır. Tüm bu bulgular neticesinde ölçeğin geçerli ve güvenilir olduğu sonucuna varılabilir. 
Demografik değişkenler ile örgütsel vatandaşlık davranışı alt boyutlarından özgecilik arasındaki ilişkiyi belirlemek için yapılan CHAID Analizi sonucunda elde edilen ağaç diyagramı Şekil 1'de gösterilmiştir.

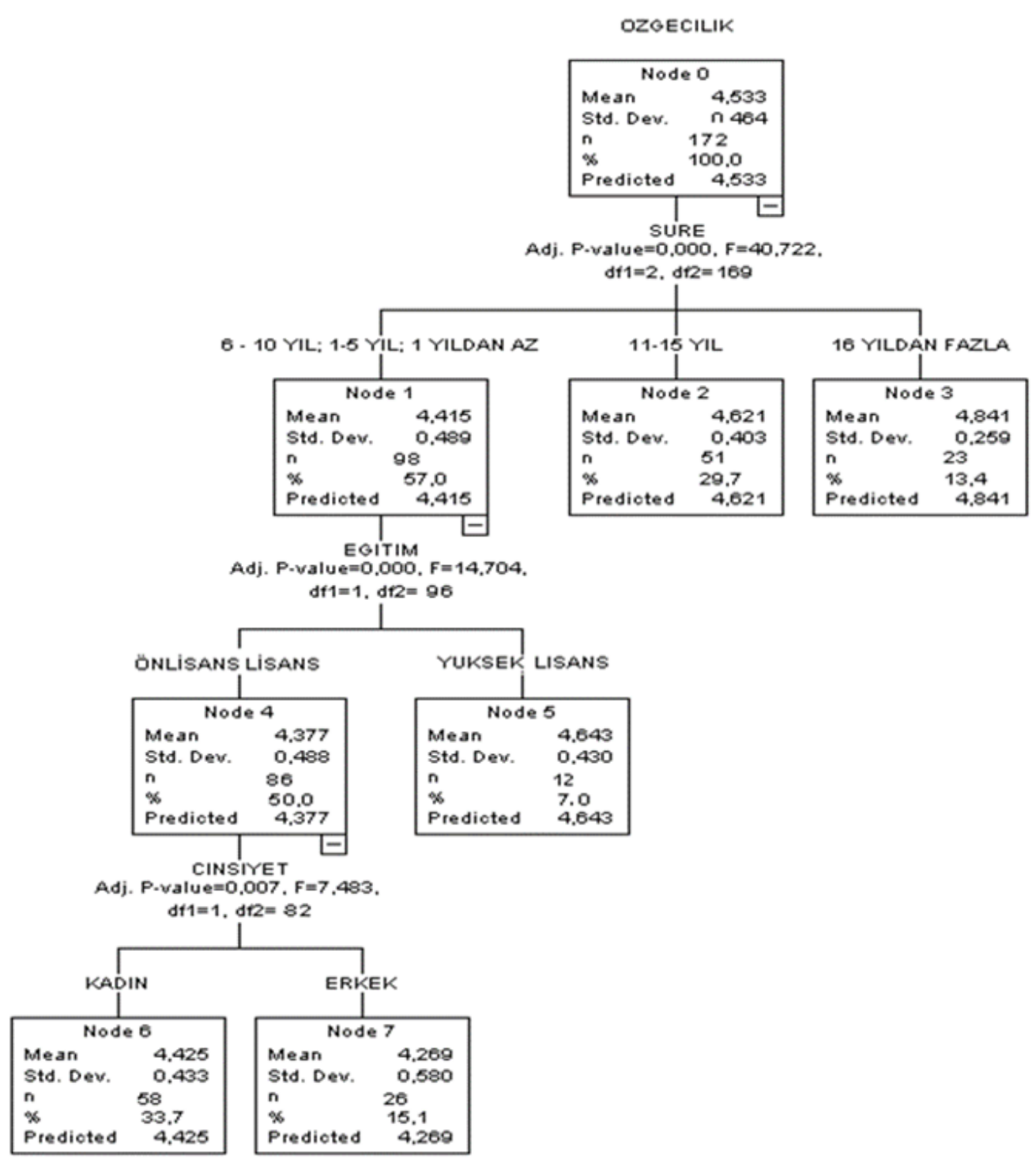

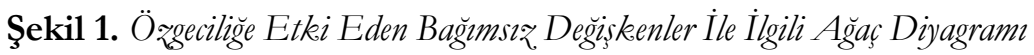

Şekil 1 incelendiğinde özgecilik ile çalışma süresi, eğitim ve cinsiyet değişkenlerinin ilişkili olduğu görülmektedir. Bunlar içerisinde özgeciliği etkileyen en önemli değişken ise çalş̧ma süresidir ( $F=40.722$, $\mathrm{p}<0.001)$.

Bülbül (2010) tarafından banka çalışanları üzerinde gerçekleştirilen araştırmada 10 yll ve üzeri çalışma süresine sahip olanların 1-3, 4-6 ve 7-9 yıl çalışanlara göre Ö.V.D göstermeye daha fazla yatkın oldukları belirlenmiştir. Bu çalışmada da 11 ile 15 yıl arasında çalışanların ortalama puanı ( $=4.621 \pm 0.403), 10$ yıldan az süredir çalışanlardan $(=4.415 \pm 0.489)$ daha yüksek iken 16 yıl ve daha fazla süreyle çalışanların ortalama puanından ( $=4.841 \pm 0.259)$ daha düşüktür. Dolayısıyla çalışma süresi artıkça çalışanların ortalama özgecilik davranışı puanları da artmaktadır. Bu bulgu Uslu ve Balcı'nın (2012) araştırma bulgularıyla uyumludur.

Çalışma süresi 10 yıldan az olan çalışanların özgecilik davranışları eğitim düzeyinden etkilenmektedir $(\mathrm{F}=14.704, \mathrm{p}<0.001)$. Ön lisans ve lisans mezunu olanların ortalama puanı $(=4.377 \pm 0.488)$ lisansüstü düzeyde eğitime sahip olanlardan $(=4.643 \pm 0.430)$ daha düşüktür. Buna benzer bir bulguya Mahnaz ve arkadaşları (2013) tarafindan eğitim hastanelerinde çalş̧anlar üzerinde gerçekleştirilen araştırmada rastlanılmaktadır. Bu çalıssmada da yüksek lisans düzeyinde eğitime sahip olanların Ö.V.D. puan ortalamaları lisans ve ön lisans düzeyinde eğitime sahip olanlardan daha yüksek bulunmuştur. 
Ön lisans ve lisans mezunu olan çalışanların özgecilik davranışları cinsiyet değişkeninden etkilenmektedir $(\mathrm{F}=7.483, \mathrm{p}<0.001)$. Buna göre kadın çalışanlar $(=4.425 \pm 0.433)$ erkek çalışanlara $(=$

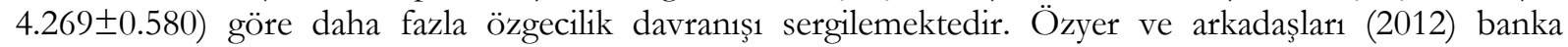
çalışanları üzerinde yaptıkları çalışmada kadınların özgecilik davranışı gösterme eğilimlerinin erkeklere göre daha yüksek olduğunu belirlemişlerdir.

Demografik değişkenler ile örgütsel vatandaşlık davranışı alt boyutlarından vicdanlılık arasındaki ilişkiyi belirlemek için yapılan CHAID Analizi sonucunda elde edilen ağaç diyagramı Şekil 2'de gösterilmiştir.

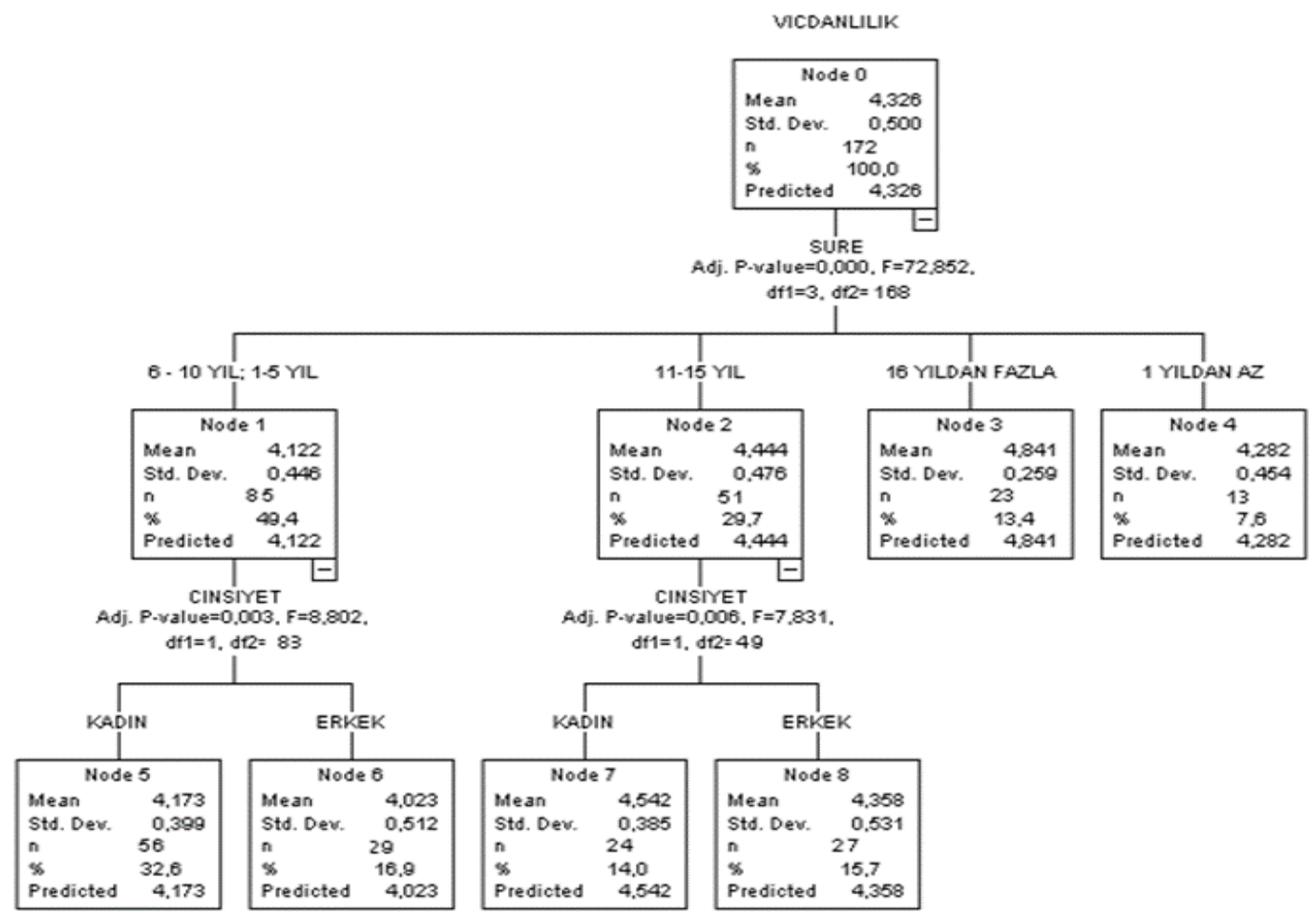

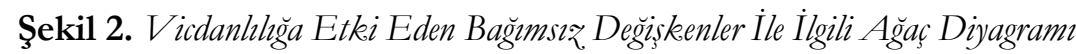

Şekil 2'ye göre vicdanlllık ile çalışma süresi ve cinsiyet değisskenleri birbiriyle ilişkilidir. Vicdanlllık üzerinde en önemli etkiye sahip olan değiş̧ken yine çalışma süresidir $(F=72.852, \mathrm{p}<0.001)$. Çalışma süresi 11- 15 yl arasında olanların vicdanllık davranışı puan ortalamaları $(=4.444 \pm 0.476), 10$ ylldan az süreli çalışanlara göre daha yüksek ( $=4.122 \pm 0.446), 16$ ylldan fazla olanlara göre ise daha düşüktür ( = $4.841 \pm 0.259)$. Dolayısıyla çalışma süresi artıkça çalışanların vicdanlılık davranışı gösterme eğilimlerinin de artığını söylemek mümkündür. Bu bulgu Mahnaz vd. (2013)'nin çalş̧ma sonuçlarıyla uyumludur. Benzer bir bulgu Uslu ve Balcı (2012) tarafından ilköğretim okullarında görev yapan öğretmenler ile yapılan çalışmada elde edilmiştir.

Çalışma süresi 10 yıldan az olanlar ile 11-15 yıl arasında olanların vicdanllık davranışları cinsiyetlerinden etkilenmektedir $(\mathrm{F}=8.802 ; \mathrm{F}=7.831, \mathrm{p}<0.001)$. Buna göre hem 10 ylldan az süreyle hem de 11-15 yıl süreyle çalşsanlar içerisinde kadınların vicdanlılık puan ortalamaları ( $=4.173 \pm 0.399$; $=$ $4.542 \pm 0.385)$ erkeklere göre daha yüksek çıkmaktadır $\quad(=4.023 \pm 0.512 ;=4.358 \pm 0.531)$. Bu bulgu Aydın'ın (2015) çalışmasıyla uyumluluk göstermektedir.

Demografik değişkenler ile örgütsel vatandaşlık davranışı alt boyutlarından nezaket davranışı arasındaki ilişkiyi belirlemek için yapılan CHAID Analizi sonucunda elde edilen ağaç diyagramı Şekil 3’te gösterilmiştir.

Şekil 3'e göre nezaket davranışı ile çalışma süresi ve medeni durum değişkenleri birbiriyle ilişkilidir. Diğer alt boyutlarda olduğu gibi nezaket davranışı üzerinde en önemli etkiye sahip olan değişken yine çalışma süresidir $(\mathrm{F}=66.107, \mathrm{p}<0.001)$. Çalışma süresi $11-15$ yl arasında olanların nezaket davranışı puan ortalaması ( $=4.732 \pm 0.344), 10$ yıldan az süreli çalışanlara göre daha yüksek $(=4.469 \pm 0.502), 16$ yıldan fazla olanlara göre ise daha düşüktür $(=4.986 \pm 0.068)$. 
Çalışma süresi 10 yıldan az olanların nezaket davranışları medeni durumlarından etkilenmektedir $(\mathrm{F}=20.087 ; \mathrm{F}=7.831, \mathrm{p}<0.001)$. Buna göre 10 yıldan az süreyle çalışanlar içerisinde evli olanların nezaket davranışı puan ortalaması $(=4.565 \pm 0.362)$ bekâr olanlara göre daha yüksek çıkmaktadır $(=4.341 \pm 0.621)$. Arıkan ve arkadaşlarının (2017) beş yıldızlı otel çalışanları üzerinde gerçekleştirdikleri araştırmada evli olan çalışanların bekâr çalışanlara oranla örgütsel vatandaşlık davranışı gösterme eğilimlerinin daha yüksek olduğu görülmüştür.

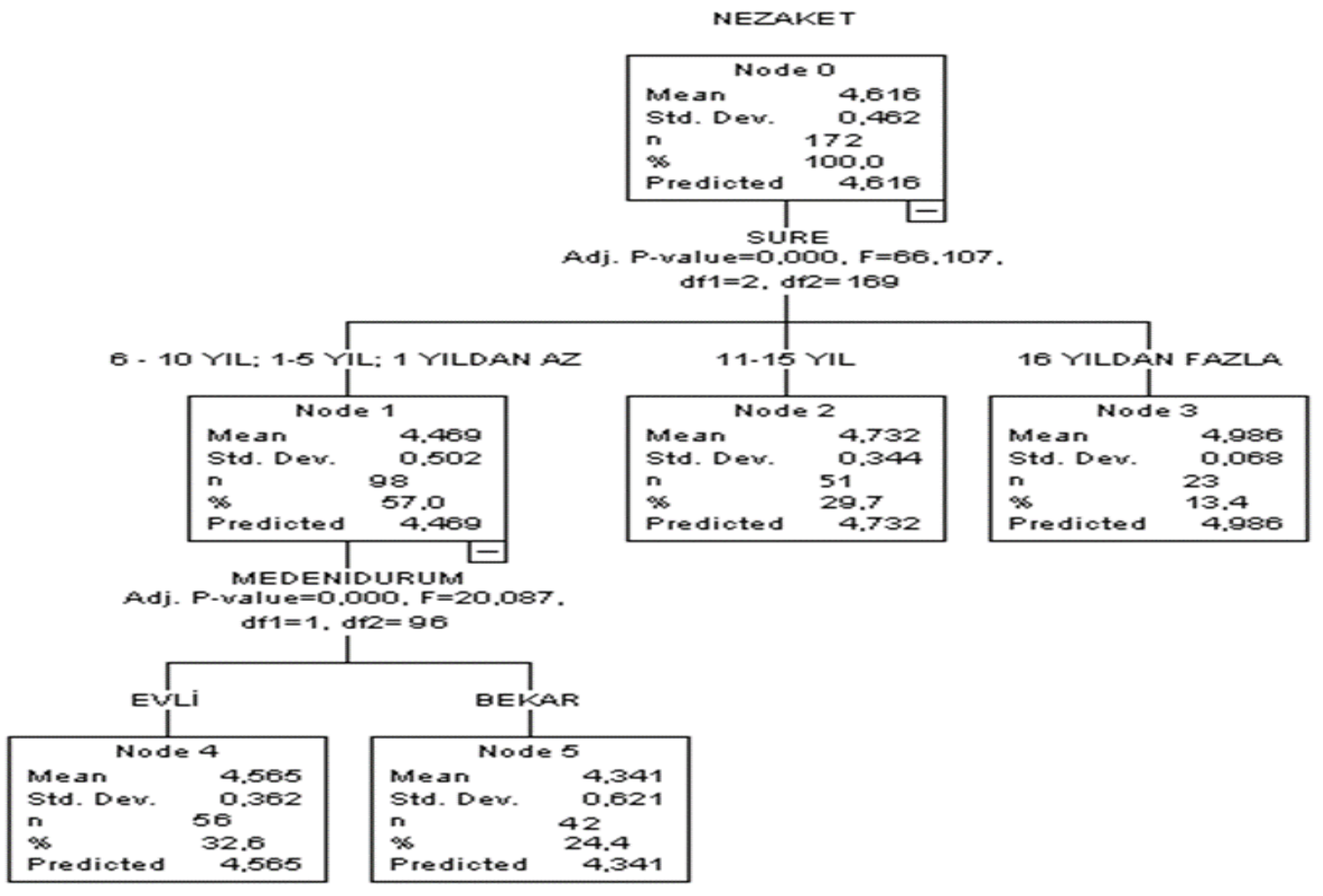

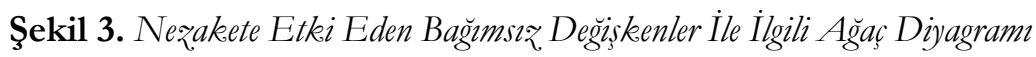

Demografik değişkenler ile örgütsel vatandaşlık davranışı alt boyutlarından centilmenlik davranışı arasındaki ilişkiyi belirlemek için yapılan CHAID Analizi sonucunda elde edilen ağaç diyagramı Şekil 4'te gösterilmiştir.

Şekil 4'e göre centilmenlik davranışı ile çalışma süresi, medeni durum ve yaş değişkenleri birbiriyle ilişkilidir. Diğer alt boyutlarda olduğu gibi centilmenlik davranışı üzerinde en önemli etkiye sahip olan değişken yine çalışma süresidir $(F=91,188, \mathrm{p}<0,01)$. Buna göre 11 y1l ve daha uzun süre çalışmış olanların centilmenlik davranışı puan ortalamaları $(=4.588 \pm 0.475) \quad 10$ yıldan az süre ile çalışanlardan daha

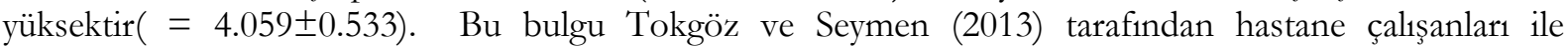
gerçekleştirilen çalışma ile uyumludur. Çalışmada örgütsel vatandaşlık davranışı boyutlarından centilmenlik boyutu üzerinde, çalışma süresinin etkili olduğu görülmüştür.

Çalışma süresi 10 yıldan az olan çalışanların centilmenlik davranışlarının aynı zamanda medeni durumdan da etkilendiği görülmektedir $(\mathrm{F}=11,953, \mathrm{p}<0,05)$. Buna göre 10 yıldan az süreyle çalışanlardan evli olanlar $(=4.170 \pm 0.470)$ bekâr olanlara göre daha fazla centilmenlik davranışı sergilemektedirler $(=$ 3.911 \pm 0.578). Bu bulgu Güleç’in (2015) otel işletmelerinde çalışan kadınların medeni durumları ile centilmenlik davranışı sergilemeleri arasında anlamlı bir farklılık olduğu yönündeki araştırma bulgusuyla tutarlılık göstermektedir. Benzer bulgu Cingi’nin (2015) çalışmasında da elde edilmiştir.

11 yıldan daha uzun süre çalışmış olanların centilmenlik davranışları ise yaş değişkeninden etkilenmektedir $(\mathrm{F}=16,555, \mathrm{p}<0,01)$. Buna göre çalışma süresi 11 y1lı aşmış olan çalışanlardan yaşları 45 ve üzeri olanların puan ortalamaları $(=4.776 \pm 0.371)$ yaşları 45 'ten az olanlara göre daha yüksektir $(=$ $4.467 \pm 0.406)$. 


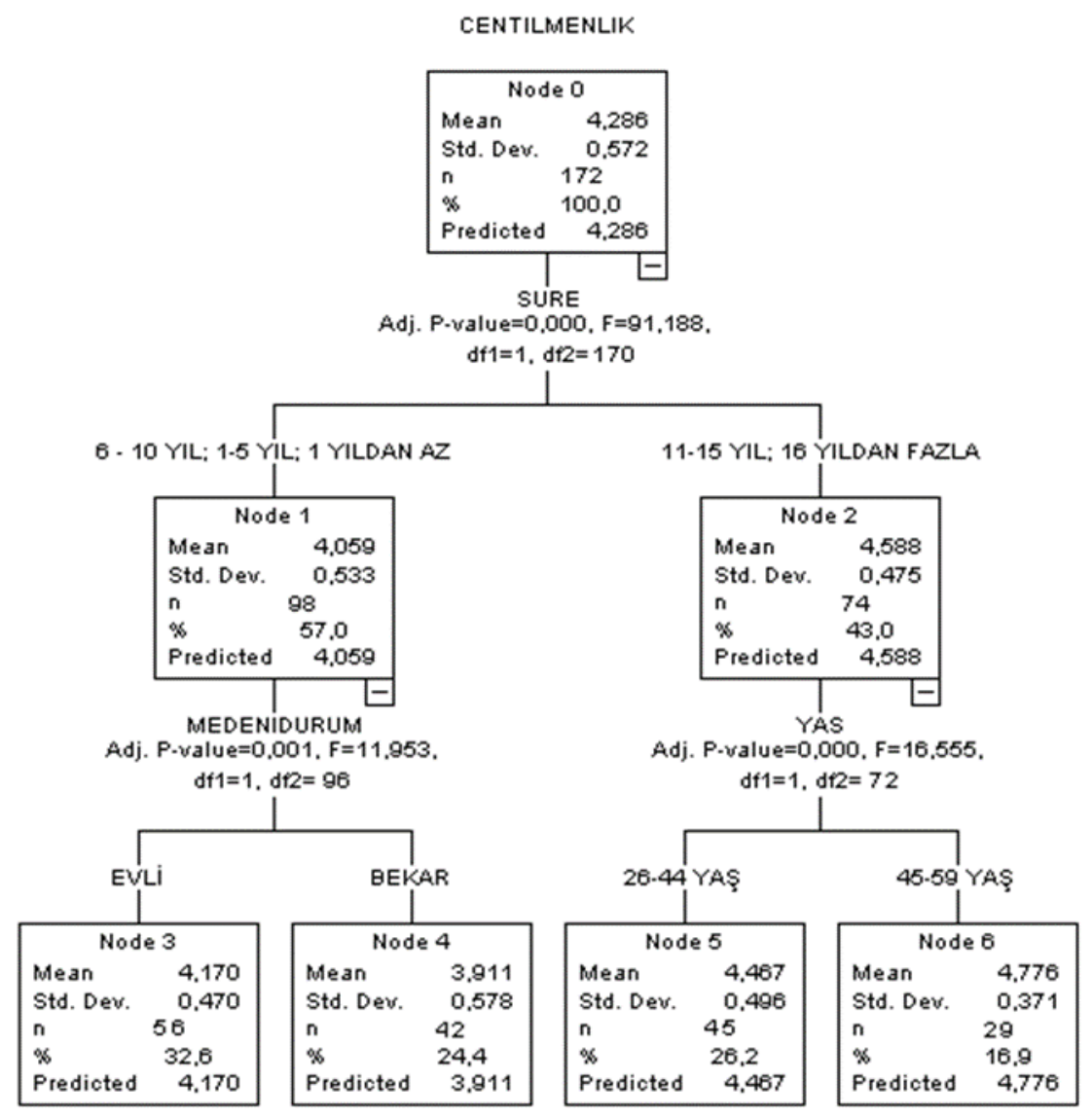

Şekil 4. Centilmenliğe Etki Eden Bağımsız. Değişkenler İle İlgili Ağac Diyagramı

Demografik değişkenler ile örgütsel vatandaşlık davranışı alt boyutlarından sivil erdem davranışı arasındaki ilişkiyi belirlemek için yapılan CHAID Analizi sonucunda elde edilen ağaç diyagramı Şekil 5'te gösterilmiştir.

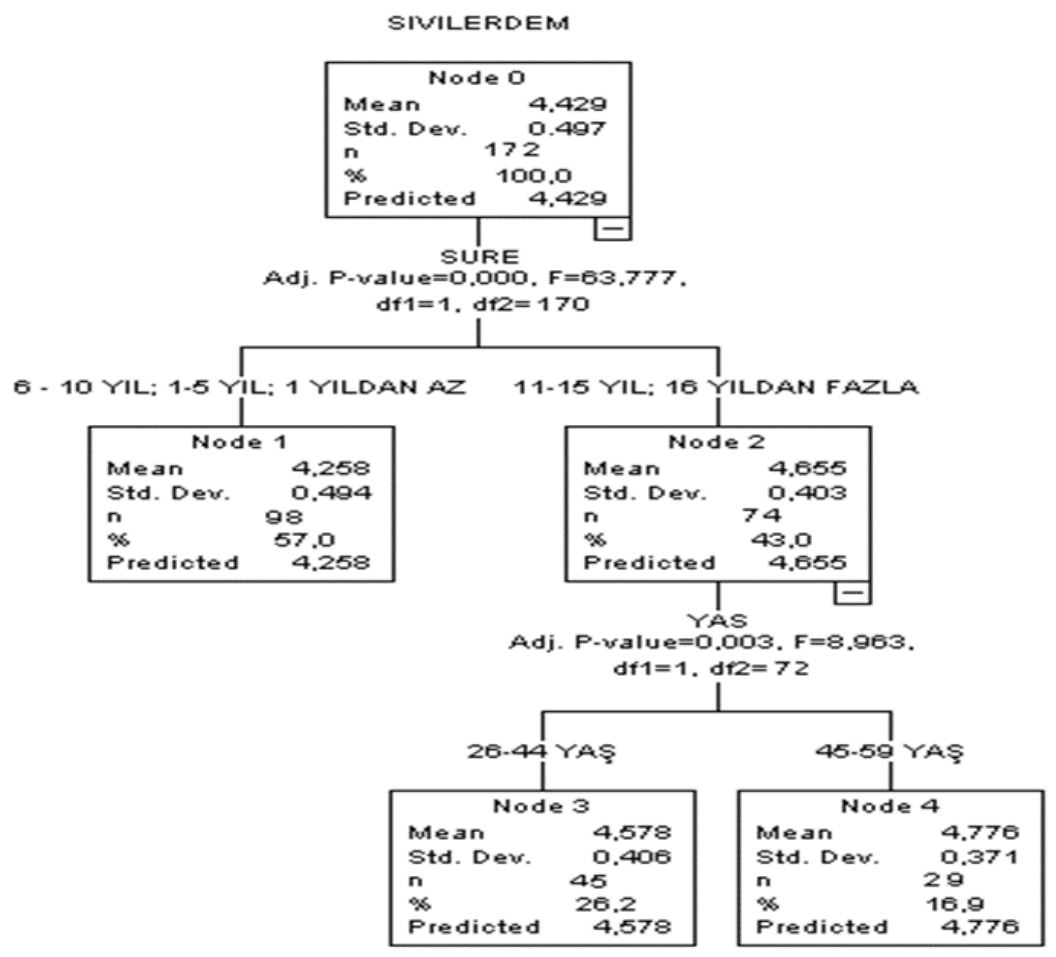

Şekil 5. Sivil Erdeme Etki Eden Băğmsıそ Değģskenler İle İlgili Ağaç Diyagramı 
Şekil 5 incelendiğinde sivil erdem davranışı ile çalışma süresi ve yaş değişkenlerinin birbiriyle ilişkili olduğu görülmektedir. Diğer alt boyutlarda olduğu gibi sivil erdem davranışı üzerinde en önemli etkiye sahip olan değişken yine çalışma süresidir $(\mathrm{F}=63,777, \mathrm{p}<0,01)$. Buna göre 11 yıl ve daha uzun süre çalışmış olanların sivil erdem davranışı puan ortalamaları $(=4.655 \pm 0.403) 10$ yıldan az süre ile çalışanlardan daha yüksektir( $=4.258 \pm 0.494)$. Benzer şekilde İzci ve Sevinç (2015) tarafindan Van il emniyet müdürlüğü çalışanları üzerinde gerçekleştirilen araştırmada 7-9 yıl aralığında çalışma süresine sahip olanlar ile 10 yıldan fazla süre ile çalışanlar arasında 10 yıl ve üzerinde çalşsanlar lehine anlamlı bir fark olduğu belirlenmiştir.

Çalışma süresi 11 yıl ve daha uzun süre olanların sivil erdem davranışları aynı zamanda yaş değişkeninden etkilenmektedir $(\mathrm{F}=8,963, \mathrm{p}<0,05)$. Buna göre çalışma süresi 11 yllı aşmış olan çalışanlardan yaşları 45 ve üzeri olanların puan ortalamaları $(=4.776 \pm 0.371)$ yaşları 45 'ten az olanlara göre daha yüksektir ( = 4.578 \pm 0.406$)$. Bu bulgu Güleç’in (2015) ve Geçer ve Esatoğlu'nun (2010) araştırma bulgularılya uyumluluk göstermektedir.

\section{Tartışma, Sonuç ve Öneriler}

1980'li yıllarla birlikte ekonomik, sosyal, politik ve teknolojik gelişmeler de hız kazanmıştır. Ülkede ve dünyada hızlı değişimlerin meydana gelmesi örgütleri de etkilemiştir. Örgütler değişim sürecine uyum sağlamak ve sürekli olarak gelişmeleri takip etmek durumunda kalmıştır. Örgütlerin değişim sürecine adapte olabilmeleri için sorumluluklarının dışına çıkan, gönüllü olarak örgütlerine katkı sağlayan ve örgütün çıkarlarını benimseyen çalışanlara ihtiyaçları vardır.

Bu çalışmada ülke ekonomisinde önemli bir yeri olan bankalarda çalışanların örgütsel vatandaşlık davranışı olarak adlandırılan ekstra rol davranışlarını sergilemelerinde demografik özelliklere atfedilebilecek bir farklılığın söz konusu olup olmadığı inceleme konusu yapılmıştır. Bu amaç doğrultusunda özel bir bankanın Denizli ili ve ilçelerindeki çalışanları araştırma kapsamına alınmıstır. İlgili analizler neticesinde elde edilen bulgular şu şekilde özetlenebilir;

- Çalışanların örgütsel vatandaşlık davranışları üzerinde en önemli etkiye sahip olan demografik özellik çalışma süresidir. Özellikle 11 yıl ve üzeri çalışma süresine sahip olan çalışanların örgütsel vatandaşlık davranışı gösterme eğilimleri 10 yıldan az süreli çalışma süresine sahip olanlarla kıyaslandığında daha yüksek çıkmaktadır. Zaten ilgili literatürde de çalışma süresinin örgütsel vatandaşlık davranışı ile yakından ilişkili olduğu ifade edilmektedir (Mahnaz vd., 2013; Tokgöz ve Seymen, 2013; Uslu ve Balc1, 2012).

- Özgecilik alt boyutu çalışma süresi, eğitim ve cinsiyet gibi demografik özelliklerle ilişkili bulunmuştur. Çalışma süresi 10 ylldan daha az olan çalışanlardan lisansüstü düzeyde eğitime sahip olanlar lisans düzeyindekilere göre; lisans mezunu olan kadınlar ise erkeklere göre daha fazla özgecilik davranışı sergilemektedirler. Bu sonuçlar literatürle uyumludur ( Şahal, 2015; Mahnaz vd., 2013; Uslu ve Balc1, 2012; Özyer vd., 2012).

- Vicdanlllık alt boyutu çalışma süresi ve cinsiyetle ilişkili bulunmuştur. Çalışma süresi 11 yıldan uzun olanların 10 yıldan kısa olanlara göre; çalışma süresi 10 yıldan kısa olanlar ile 11-15 yıl arasında olanlardan kadınların erkeklere göre daha fazla vicdanlılık davranışı sergiledikleri görülmüştür. Bu bulgular da literatürle uyumluluk göstermektedir (Aydın, 2015; Cingi, 2015; Mahnaz, 2013; Uslu ve Balc1, 2012).

- Nezaket alt boyutu çalışılan süre ve medeni durumla ilişkili bulunmuştur. Çalışma süresi 11 yıldan uzun olanların 10 yıldan daha kısa süreli olanlara göre; çalışma süresi 10 yıldan kısa olanlardan da evli olanların bekâr olanlara göre nezaket davranışı gösterme eğilimlerinin daha yüksek olduğu görülmüştür. Bu bulgu da literatürle uyumludur (Arıkan vd., 2017; Cingi, 2015; Uslu ve Balc1, 2012).

- Centilmenlik alt boyutu çalışma süresi, medeni durum ve yaş gibi demografik özelliklerle ilişkili bulunmuştur. Çalışma süresi 11 yıldan fazla olanların 10 ylldan az olanlara göre; çalışma yılı 10 yıldan az olanlardan evli olanların bekâr olanlara göre; çalışma yilı 11 yıldan fazla olanlardan da 45 yaş ve üzeri olanların 45 yaşın altında olanlara göre daha fazla centilmenlik davranışı sergiledikleri belirlenmiştir. Bu bulgular da literatüre uyum sağlamaktadır (Güleç, 2015; Cingi, 2015; Tokgöz ve Seymen, 2013).

- Sivil erdem alt boyutu çalışma süresi ve yaş ile ilişsili bulunmuştur. Buna göre çalışma süresi 11 yıldan fazla olanların 10 yıldan daha az olanlara göre; çalışma süresi 11 yıldan fala olanlardan da yaş1 45 ve üzeri olanların 45 'ten küçük olanlara göre sivil erdem davranışı gösterme eğilimleri 
daha yüksek bulunmuştur. Bu bulgu da literatürden destek bulmaktadır (Güleç, 2015; Geçer ve Esatoğlu, 2010).

Ülke ve dünyada meydana gelen değişimler yoğun rekabete neden olmaktadır. Örgütler, çalışanlarının etkinliğini ve verimliliğini arttırmak suretiyle ancak bu rekabetle baş edilebilir hale gelebilirler. Bankacıllk sektörü de değişen bu piyasa koşullarından oldukça etkilenmektedir. Müşteri beklentilerine kısa zamanda cevap verebilmek ve kaliteli hizmet sunabilmek bankacılık sektörü için oldukça önemlidir. Personelin eğitilmesi ve geliştirilmesi, örgüt içinde etkin bir iletişim ağı kurulması, bilginin açık ve anlaşlır bir biçimde paylaşılması, personelin ortak bir amacı benimsemesi bankacıllk sektöründe hızlı ve iyi bir hizmet sunulmasının ön koşulu haline gelmiştir. İleri görev bilincine sahip, yardımlaşma kültürünü edinmiş, etki alanı genişlemiş, beklenenin ötesinde örgüt yararına fazladan rol davranışında bulunan, çözüm odaklı olan, risk alabilen banka çalışanları diğer hizmet sektörlerinde olduğu gibi bu sektörde de başarıyı sağlayacaktır.

\section{Etik Beyan}

“Örgütsel Vatandaşlık Davranışı İle Demografik Özellikler Arasındaki İlişkinin CHAID Analizi İle İncelenmesi: Bankacılık Sektöründe Bir Araştırma" başlıklı çalışmanın yazım sürecinde bilimsel, etik ve alıntı kurallarına uyulmuş; toplanan veriler üzerinde herhangi bir tahrifat yapılmamış ve bu çalışma herhangi başka bir akademik yayın ortamına değerlendirme için gönderilmemiştir.

\section{Kaynakça}

Ala, Ş., (2010). Personeli güclendirmenin, örgütsel vatandaşlı davranışı üzerindeki etkisinde etiksel davranısın rolü (Yüksek Lisans Tezi) Selçuk Üniversitesi Sosyal Bilimler Enstitüsü, Konya.

Alkahtani,A. (2015). Organizational citizenship bahavior and rewards. International Business Research, 8(4), $210-222$. DOI:10.5539/ibr.v8n4p210

Allison, B. vd., (2001). Student classroom and career success: the role of organizational citizenship behavior. Journal of Education for Business, 76(5), 282-288. doi.org/10.1080/08832320109599650

Arıkan, E., Kılıç, G. ve Becerikli, G. (2017). karizmatik liderlik ve örgütsel vatandaşlık davranışı arasındaki ilişki: kuşadası'ndaki beş yıldızlı otel işletmelerinde bir uygulama. Türk Turiz̧m Araştırmalar Dergisi, 1(4), 1-19. DOI: $10.26677 /$ tutad.2017.15

Atti, A. ve Dodo, D. (2018). Chi-Square automatic interaction detection (CHAID) analysis for home quality status segmentation. American Journal of Engineering Research, 7(4), 183-188.https://www.researchgate.net/ publication/324744253_ChiSquare_Automatic_Interaction_Detection_Chaid_Analysis_for_Home_Quality_St atus_Segmentation

Avcı, A., (2015). Öğretmenlerin örgütsel vatandaşlık davranışlarına ilişkin görüşleri. Marmara Üniversitesi Atatürk Eğitim Fakültesi Eğitim Bilimleri Dergisi, 42, 191-206. http://www.akademikbakis.org

Aydın, Y. (2015). Liderlik tarælar ile örgütsel vatandaşllk davramısı arasındaki iliskide örgüt kültürünün rolü: bursa serbest bölgesinde faaliyet gösteren firmalar üzerine bir araştırma (Doktora Tezi). Çukurova Üniversitesi Sosyal Bilimler Enstitüsü, Adana.

Aydoğan, E. ve Dinçer E., (2017). Örgütsel iklim ve örgütsel vatandaşlık davranışı arasındaki ilişki: Kalkınma bakanlığ1 örneği. Gaz̨i Üniversitesi Sosyal Bilimler Dergisi, 9, 48-66. http://www.academia.edu/32024342/

Bakan, İ., Büyükmeşe, T., Erşahan, B. ve Kaya, İ. (2017). Demografik özellikler kapsamında çalışanların örgütsel vatandaşlık davranışı ve örgütsel kimlik algıları: Bir alan araştırması. Akademik. Araştırmalar Ve Calışmalar Dergisi, 9(17), 167-182. http://dergipark.gov.tr/download/article-file/369674

Basım, H. ve Şeşen, H., (2006). Örgütsel vatandaşlık davranışı ölçeği uyarlama ve karşılaştırma çalışması. Ankara Üniversitesi Sosyal Bilimler Fakültesi Dergisi, 61(4), 83-101. http://dergipark.ulakbim.gov.tr/ausbf/article/viewFile/ $5000093061 / 5000086527$.

Berbaoui, K., Slimani, I. ve Sadek, Z. (2015). The relationship between demographic characteristics and organizational citizenship behavior in the national company for distribution of electricity and gas. International Journal of Innovative Research in Engineering \& Management, 2(6), 8-11. http://www.ijirem.org/DOC/2_\%20IREM246f2bd9285-73f6-461e-b554-f5c5 5cc03cc6.pdf

Bolino, M. C. (1999). Citizenship and impression management: good soldiers or good actors? Academy of Management Rewiew, 24(1), 82-98. http://web.mit.edu/curhan/www/docs/Articles/15341_Readings/Selfpresentation_Impression_Formation/Bolino_1999_Citizenship_and_impression_management.pdf

Budak, G. (2015). Psikolojik dayanıklilk ve örgütsel adalet algisımın örgütsel vatandaşlık davramışı üzerine etkisi (Yüksek Lisans Tezi). Başkent Üniversitesi Sosyal Bilimler Enstitüsü, Ankara.

Bülbül, A. (2010). Calışanlarn örgütsel adalet algısmın, örgütsel vatandaşlık ve örgütsel bağhliğg etkisi üzerine bir çalısma (Yüksek Lisans Tezi). Trakya Üniversitesi Sosyal Bilimler Enstitüsü, Edirne.

Cingi, A. (2015). Örgütsel vatandaşlı davranış ve iş tatmini ilişkisine yönelik bir araştırma (Yüksek Lisans Tezi). İstanbul Üniversitesi Sosyal Bilimler Enstitüsü, İstanbul. 
Çelik, M. (2007). Örgüt keültürü ve örgütsel vatandaşlık davranış (Doktora Tezi). Atatürk Üniversitesi Sosyal Bilimler Enstitüsü, Erzurum.

Çelik, M. (2010). Öğretmen görüslerine göre okul yöneticilerinin ögretimsel liderlik davramısı ile ögretmenlerin örgütsel vatandaşlı davranıslarmın analiæi (Yüksek Lisans Tezi). Selçuk Üniversitesi Eğitim Bilimleri Enstitüsü, Konya.

Çetinkaya, M. ve Çimenci, S. (2014). Örgütsel adalet algısının örgütsel vatandaşlık davranışı üzerindeki etkisi ve örgütsel özdeşleşmenin aracılık rolü: yapısal eșitlik modeli çalışması. Yönetim Bilimleri Dergisi, 12(23), 237-278. http://acikerisim.lib.comu.edu.tr:8080/xmlui/handle/COMU/778

Doğan, İ. (2003). Holştayn 1rk1 ineklerde süt verimine etki eden faktörlerin CHAID ana1izi ile incelenmesi. Ankara Üniversitesi Veterinerlik Fakültesi Dergisi, 50, 65-70. http://dergiler.ankara.edu.tr/dergiler/11/946/11735.pdf

Geçer, H. ve Esatoğlu, A.E. (2010). Hemşirelerin örgütsel vatandaşlık düzeylerinin belirlenmesi. Ankara Üniversitesi Dikimevi Sağhk Hizmetleri Meslek Yülksekokulu Dergisi, 9(2), 35-51. http://dergipark.gov.tr/download/issuefile/8967

Güleç, M. (2015). Kadın çalışanlarda cam tavan sendromunun örgütsel vatandaşliğa etkileri kusadası 4 ve 5 ynldı̨̧ otel işletmelerinde bir uygulama (Yüksek Lisans Tezi). Adnan Menderes Üniversitesi, Sosyal Bilimler Enstitüsü, Aydın.

Gürbüz, S., (2006). Örgütsel vatandaşlık davranışı ile duygusal bağlllık arasındaki ilişkilerin belirlenmesine yönelik bir araştırma. Ekonomike ve Sosyal Araştrrmalar Dergisi, 3(2), 48-75. http://iibfdergi.ibu.edu.tr/index.php/ijesr/ article/view/28

İzci, F. ve Sevinç, H. (2015). Kurumsal vatandaşlık davranışı boyutlarının araştırılması ve analizi: Van il emniyet müdürlüğü örneği. Bartın Üniversitesi İ.I.B.F. Dergisi, 6(12), 53-78.

Karaman, A. ve Aylan, S., (2012). Örgütsel Vatandaşlik, Kahramanmaraş Sütçü İmam Üniversitesi İktisadi ve İdari Bilimler Fakültesi Dergisi, 2(1), 35-48. http://iibfdergisi.ksu.edu.tr/issue/10264/125885

Khan, H., Yasir, M., Yusof, H. M., Saleem, M. M. ve Khan, N.U. (2017). A review of the conceptualization of organizational citizenship behavior. City University Research Journal, Special Issue, 81-87. http://www.cityuniversity.edu.pk/ curj/Journals/Journal/special_aic_16/9.pdf

Kittilertpaisan, J., Chanchiprecha, C. ve Phoonkasem, C. (2014). At the first glance of organizational citizenship behaviors and organizational effectiveness: A study of city and town municipality in Thailand. Universal Journal of Management, 2(8), 161-166. DOI: 10.13189/ujm.2014.020807

Mahmutoğlu, T. (2017). Isş hayatında cinsel ayrmallk ve örgütsel vatandaşlık davranısı üzerine etkileri (Yüksek Lisans Tezi). Hacettepe Üniversitesi Sosyal Bilimler Enstitüsü, Ankara.

Mahnaz, M. A., Mehdi, M., Jafar, K. M. ve Abbolghasem, P. (2013). The effect of demographic characteristics on organizational citizenship behavior in the selected teaching hospitals in Tehran. African Journal of Business Management, 7(34), 3324-3331. DOI: 10.5897/AJBM2013.7117

Moorman, R. (1991). Relationship between organizational justice and organizational citizenship behaviors: do fairness perceptions influence employee citizenship? Journal of Applied Psychology, 76(6), 845-855. http://psy482.cankaya.edu.tr/uploads/ files/Relationship\%20between \%20OCB\%20and\%20OJ.pdf

Organ, D. W. (1988). Organizational citizenship behavior: The good soldier syndrome. Lexington, M.A., Lexington Books.

Özyer, K., Orhan, U. ve Orhan, D. D. (2012). Demografik özelliklerin örgütsel vatandaşlık davranışının alt boyutları ile ilişkisi: bankacılık sektöründe bir uygulama. Dokuz. Eylül Üniversitesi İktisadi ve İdari Bilimler Fakültesi Dergisi, 27(1), 181-204. https://iibfdergi.deu.edu.tr/index.php/cilt1-sayi1/article/view/306

Podsakoff, M. P., MacKenzie, S. B., Paine, J. B. ve Bachrach, D. G. (2000). Organizational citizenship behaviors: A critical review of the theoretical and empirical literature and suggestions for future research. Jounal of Management, 26(3), 513-563. https://pdfs.semanticscholar.org/b2c3/a1f19d7f425dce3485beac95 e0264441736f.pdf

Podsakoff, P. M. ve MacKenzie, S. B. (1997). Impact of organizational citizenship behavior on organizational performance: a review and suggestions for future research. Human Performance, 10(2), 133-151. doi.org/10.1207/s15327043hup 1002_5

Savram, M. ve Karakoç, A. (2012). Bankacilık sektöründe itibar riskinin önemi. International Conference On Eurasian Economies, 328-332.

Sığmaz, A. (2017). İs doyumunun örgütsel bağhliğa etkisi: bankachllk sektörü üz̧erine bir araştırma (Yüksek Lisans Tezi). Pamukkale Üniversitesi Sosyal Bilimler Enstitüsü, Denizli

Spector, P. E. ve Fox, S. (2002). An emotion-centered model of voluntary work behavior some parallels between counterproductive work behavior and organizational citizenship behavior. Human Resource Management Review, 12, 1-24. doi.org/10.1016/S1053-4822(02)00049-9

Şahal, S. (2015). Örgütsel adaletin örgütsel vatandaşlı davranışına etkisi (Yüksek Lisans Tezi). Gazi Üniversitesi Sosyal Bilimler Enstitüsü, Ankara.

Şahin, S. ve Acar, V., (2017). İnternet bağımlılı̆̆1 ve örgütsel vatandaşlık davranış1: hastanelerde uygulanan bir araştırma. Uluslararası Yönetim ve İsletme Dergisi, 17, 1094-1103. doi.org/10.17130/ijmeb. 2017ICMEB1735882

Şahin, S. Ş. ve Avcıkurt, C. (2013). Turist rehberlerinin iletişim yeterlilikleri: turistlerin görüşlerinin chaid analizi ile değerlendirilmesi. Balkesir Üniversitesi Sosyal Bilimler Enstitüsü Dergisi, 16(29), 303-327. http:/ / sbe.balikesir.edu.tr/ dergi/edergi/c16s29/makale/303-327.pdf

Tambe, S. ve Shanker, M. (2014). A study of organizational citizenship behaviour (OCB) and 1ts dimensions: A literature review. International Research Journal of Business and Management, 1, 67-73. 
https://www.researchgate.net/publication/282239572_A_Study_of_Organizational_Citizenship_Behaviour_O CB_and_Its_Dimensions_A_Literature_Review

Tokgöz, E. ve Seymen, A. (2013). Örgütsel güven, örgütsel özdeşleşme ve örgütsel vatandaşlık davranışı arasındaki ilişki: Bir devlet hastanesinde araştırma. Öneri, 10(39), 61-76. http://dergipark.gov.tr/download/articlefile/165796

Ulusoy, H. ve Sarıçoban, S. (2017). Hekimlerin örgütsel vatandaşlık düzeylerinin kurumda çalışmaktan memnuniyet durumlarının ve kurumda kalma niyetlerinin incelenmesi. Uluslararası Sosyal Arasstırmalar Dergisi, 10(48), 659-668. DOI: $10.17719 /$ jisr.2017.1538

Uslu, B. ve Balc1, E. (2012). İlköğretim okulu öğretmenlerinin örgütsel vatandaşlık davranışları ile örgütsel iletişim algiları arasındaki ilişki. Kuram ve Uygulamada Ë̆itim Yönetimi, 18(3), 461-489. https://www.pegem.net/dosyalar/dokuman/136517-20121127121547-makale-5.pdf

Uzonwanne, F. (2014). Organizational citizenship behaviour and demographic factors among oil workers in Nigeria. IOSR Journal Of Humanities And Social Science, 19(8), 87-95. DOI: 10.9790/0837-19858795

Ünal, M. (2014). İzmir Ticaret Odas1 Ar-Ge Bülten Eylül-2014 - Ekonomi. İzmir.

Yeşiltaş, M. ve Keleş, Y. (2010). Otel işletmesi işgörenlerinin örgütsel vatandaşlık davranışlarının demografik özelliklerine göre karşılaştırılması. Erciyes Üniversitesi İktisadi ve İdari Bilimler Fakültesi Dergisi, 36, 113-132 http://iibf.erciyes.edu.tr/dergi/sayi36/008_yesiltas-keles.pdf

Yoon, C., (2009). The effect of organizational citizenship behaviors on erp system success. Computers in Human Behavior, 25, 421-428. doi.org/10.1016/j.chb.2008.10.004

Yücel, C. ve Kaynak, S. (2008). Öğretmenlerin kişilik özellikleri ve örgütsel vatandaşlık davranışı. Selçuk Üniversitesi Sosyal Bilimler Fakültesi Dergisi, 20, 686-706. https://www.researchgate.net/publication/26590072.

\section{EXTENDED ABSTRACT}

Human factor underlies the success and productivity of organizations in today's business world. The organizations struggling to survive in an intensely competitive environment need employees who go beyond their work descriptions and undertake extra tasks, fulfill their tasks literally without any inspection mechanisms, provide in-house solidarity and care about organizational confidentiality. These behavior patterns, which are called organizational citizenship, have drawn much attention and been studied by many researchers. Organizational citizenship comprises behaviors that are not included in the work description, that occur regardless of any training and are not subject to rewarding or punishing systems. It is possible to address these behaviors in two different types. First are the behaviors that are actively listed among organizational activities. In this type of behavior which aims at contributing to the organization, employees play an active role in the organization. They produce with their own effort. The second type of organizational citizenship behavior appears as avoiding behaviors that will damage organizational structure. The employees behave merely with the intent of not damaging the organization. The main idea is not to do anything that will damage the organization. The difference between these two behavior types is like a football game. It is not the same to play to win and to play not to lose. Although basically organizational citizenship is addressed in two different ways, in practice both are demanded and are among the list of behaviors expected from the employees by the organizations.

When relevant literature is examined, it is observed that organizational citizenship behavior is usually addressed in five sub-dimensions namely altruism, conscientiousness, courtesy, sportsmanship and civil virtue. Whereas altruism and courtesy sub-dimensions are related to the individual; conscientiousness, sportsmanship and civil virtue sub-dimensions are related to the organization. Altruism is the whole of the behaviors aiming at helping the individuals in the organization. It is to help your colleagues who need help or who have just started to work without their demand of your own accord. It is also possible to describe it as the communication of experience and knowledge by the senior and expert personnel to the employees that have recently started working. Altruism with solidarity standing out, contributes to the increase of organizational effectiveness and productivity. The use of tools and equipment in the organization or the studies complementing each other by exchanging knowledge while preparing for a project or a presentation are among the good examples of altruism. Courtesy is to prevent situations that could cause problems voluntarily without waiting for a problem to occur. Behaviors such as informing employees early, counseling or reminding them are examples of courtesy behaviors. Though altruism and courtesy look like very similar concepts, there are some differences. Whereas altruism refers to behaviors appearing after problem has occurred, courtesy refers to the behaviors aiming at preventing a problem from occurring. Conscientiousness is the behavior of obeying the rules providing organizational order. It is the employees' eagerness and intention to obey the rules. Conscientious sub-dimension is also defined as "personal effort", "advanced sense of mission" and "overall adaptation". That the employees undertake extra responsibilities voluntarily in order to increase success and performance of the organization, behave 
creatively and be innovative, and encourage their friends to behave likewise are examples of conscientious dimension behavior patterns. Civil virtue is about employees' organizational commitment and sense of responsibility. Participating in every meeting held in the organization, expressing their thoughts freely in arguments during the meetings, participating in organizational decisions, having trainings to improve themselves, observing situations and conditions that can be perceived as opportunity or threat for the organization, having knowledge about the organization are among behavior patterns that can appear in civil virtue dimension. Sportsmanship is behaviors of avoiding. Employees avoid from behaviors that they think could cause problems. It can also be characterized as employee's approaching a problem with a positive attitude, sacrifice themselves even if there is not a consensus between employees, respecting others' feelings and thoughts.

Like all organizations, banks as well demand to have a workforce that have developed commitment, and put voluntary effort beyond responsibilities. In this context, the behaviors expected from the employees can be regarded as organizational citizenship behaviors.

Organizational citizenship behavior reflects on the employees' performances and influences them positively or negatively. This has become a behavior pattern expected from their employees by the organizations due to the necessity to easily adapt to the changes occurring in the organizational life. The objective of the study is to explore the relationship between organizational citizenship behavior which influences both the organization and the employees positively, and various demographic properties. For this purpose, the study was conducted with 172 employees of a private bank. The necessary data was collected via survey. CHAID analysis was utilized for data analysis. This analysis was preferred because it does not require assumptions (such as normality, linearity, homogeneity) necessary for regression analysis. As a result of the analyses made, tenure was found to be the most influential demographic property on organizational citizenship behavior. Besides, the demographic properties related to organizational citizenship behavior sub-dimensions can be summarized as: Altruism sub-dimension is related to tenure, education and gender; conscientiousness sub-dimension is related to tenure and gender; courtesy subdimension is related to tenure and marital status; sportsmanship sub-dimension is related to tenure, marital status and age; and civil virtue sub-dimension is related to tenure and age. 